\title{
Cytogenetic analyses as clarifying tools for taxonomy of the genus Callisia Loefl. (Commelinaceae)
}

\section{Análisis citogenéticos como herramienta para esclarecer la taxonomía del género Callisia Loefl. (Commelinaceae)}

\author{
Marina Grabiele ${ }^{1,2^{*}}$, Julio R. Daviña ${ }^{1} \&$ Ana I. Honfi ${ }^{1}$ \\ ${ }^{1}$ Programa de Estudios Florísticos y Genética Vegetal (PEFyGV), Instituto de Biología Subtropical (IBS UNaM - \\ CONICET), Universidad Nacional de Misiones, Rivadavia 2370, 3300 Posadas, Argentina. \\ ${ }^{2}$ Instituto de Botánica del Nordeste (IBONE-CONICET), Universidad Nacional del Nordeste, C.C. 209, 3400 \\ Corrientes, Argentina. \\ *marinagrabiele@hotmail.com
}

\begin{abstract}
Chromosome numbers, karyotypes and meiotic behaviour in 10 populations belonging to two species of Callisia Loefl. from Northeast Argentina have been studied. Callisia repens showed a basic number of $\mathrm{x}=6$ and that of $C$. monandra was $\mathrm{x}=7$. Both species were diploids and this is the first report of the chromosome numbers for Argentinean populations: C. repens, $2 \mathrm{n}=2 \mathrm{x}=12$ and C. monandra $2 \mathrm{n}=2 \mathrm{x}=14$. The karyotype descriptions of $C$. repens $(2 \mathrm{~m}+2 \mathrm{sm}+6 \mathrm{st}+2 \mathrm{t})$ and $C$. monandra $(6 \mathrm{~m}+4 \mathrm{sm}+4 \mathrm{st})$ are also reported here for the first time for both species. Chromosomes behaved regularly at meiosis, pair as bivalents and produced viable pollen in the Callisia accessions studied. Chiasmata frequency and distribution are reported and this meiotic analysis constituted a novelty for each species. The information provided in this paper is useful for the cytogenetics diagnosis of the genus and the subtribe and contribute to understand relationships between taxa.
\end{abstract}

KeYwORDS: Basic chromosome number, karyotype, microsporogenesis, chiasma.

\section{RESUMEN}

Se han analizado los números cromosómicos, los cariotipos y el comportamiento meiótico en 10 poblaciones pertenecientes a dos especies de Callisia Loefl. provenientes del Nordeste de Argentina. Callisia repens mostró un número básico $\mathrm{x}=6$ mientras que el de C. monandra fue $\mathrm{x}=7$. Ambas especies fueron diploides y éste es el primer reporte de los números cromosómicos para poblaciones Argentinas: $C$. repens, $2 \mathrm{n}=2 \mathrm{x}=12$ y C. monandra $2 \mathrm{n}=2 \mathrm{x}=14$. Las descripciones cariotípicas de C. repens $(2 \mathrm{~m}+2 \mathrm{sm}+6 \mathrm{st}+2$ t) y C. monandra $(6 \mathrm{~m}+4 \mathrm{sm}+4 \mathrm{st})$ también han sido analizadas por primera vez para ambas especies. En meiosis, los cromosomas se comportaron regularmente, se aparearon como bivalentes y produjeron polen viable en ambas especies de Callisia estudiadas. Se analizó la frecuencia y distribución de quiasmas y este análisis meiótico también constituye una novedad para cada especie. La información que se provee en este trabajo es útil para la diagnosis citogenética del género y la subtribu así como para contribuir a la comprensión de las relaciones entre los taxa.

Palabras clave: Número cromosómico básico, cariotipo, microesporogénesis, quiasma.

\section{INTRODUCTION}

Callisia Loefl. comprises about 20 species from Southwest USA and Tropical America, of which occur in Mexico (Faden 1998, Hunt 1983). In Argentina just two are native: Callisia repens L. and C. monandra Schult. \& Schult.f. This genus is included into subtribe Tradescantiinae which has undergone taxonomic reorganization because some species do not fit into the diagnostic characters of genera that compose. The most important modification in the relations between taxa of Commelinaceae was proposed by Hunt (1986), which included some of the species of Tradescantiinae into the genus Callisia, expanding and establishing five different sections. These sections were established according to morphological and karyological features (Hunt 1986). Callisia repens belongs to section Callisia that includes ten Neotropical species, with a basic number $\mathrm{x}=6$. Only four species have been karyologically analyzed: $C$. fragrans (Lindl.) Woodson ( $2 \mathrm{n}=12), C$. gentlei Matuda $(2 \mathrm{n}=12), C$. soconuscensis Matuda $(2 \mathrm{n}=12)$, and C. repens $2 \mathrm{n}=12,24)$. Callisia repens is distributed from Mexico and The Indies to the South of Brazil, Paraguay and North of Argentina. In Argentina, this species was collected in Tucumán, Misiones and Entre Ríos (Bacigalupo 1964). Callisia monandra is included in section Leptocallisia, whose six species are distributed from Florida, Texas, México and Tropical America, and have a basic number $\mathrm{x}=7$ (Tucker 1989). Callisia monandra is distributed in North Misiones 
(Argentina), South Mexico, The Indies and Central America (Bacigalupo 1964, 1996).

Previous karyotype analysis showed that Callisia species vary considerably in the number and morphology of their chromosomes and chromosome numbers of 15 species have been published, where diploid, polyploid and aneuploid cytotypes were found, with 13 different somatic chromosome numbers, going from $2 n=12$ to $2 n=72$ (Faden 1998). Most of the species recorded so far have at least a diploid cytotype with $2 \mathrm{n}=12(60 \%)$ or $2 \mathrm{n}=14(27 \%)$ chromosomes, $40 \%$ of the species have polyploid cytotypes and $20 \%$ have both diploid and polyploid cytotypes; some species show an aneuploid (25\%) plus the euploid cytotype (Jones \& Jopling 1972, Faden 1998).

Regarding the ancestral basic chromosome number of Callisia, Handlos (1970) and Jones \& Jopling (1972) have proposed $x=6(\mathrm{ca} .70 \%$ of the species recorded $)$, although there have been found species with $\mathrm{x}=7$ and $\mathrm{x}=8$. Callisia species showed asymmetrical and unimodal karyotypes skewed with large chromosomes and most of the species can be recognized by its distinctive karyotype morphology (Jones \& Jopling 1972). The karyotype formulas from a few of these species are known, some of which have been meiotically analyzed. However the chromosome information from populations of Argentina is not available yet and, a more detailed cytogenetic analysis is needed to the understanding of the relationships within the genus.

The aims of this work were to study the chromosome numbers, karyotypes and meiotic behaviour of Callisia repens and $C$. monandra in order to provide new useful tools in order to circumscribe genus Callisia which, despite extensive anatomical, morphological and molecular level studies, is still taxonomically confused.

\section{MATERIAL AND METHODS}

Ten populations of Callisia repens and C. monandra native from Northeast Argentina were studied (Table I). Voucher specimens were deposited at the herbarium of the Universidad Nacional de Misiones (MNES), and duplicates at Instituto de Botánica del Nordeste (CTES) and Instituto de Botánica Darwinion (SI) herbaria.

Meiotic studies were carried out in young floral buds without fixation, or fixed in absolute ethanol : glacial acetic acid $(3: 1)$ for at least $12 \mathrm{~h}$ at $4{ }^{\circ} \mathrm{C}$ and then stored in $70 \%$ ethanol (Grabiele et al. 2005). Bivalent and chiasma frequencies were estimated by analysis of 30 pollen mother cells (PMCs) at diakinesis or metaphase I for each species. PMCs were stained with $2 \%$ aceto-carmine and pollen stainability was estimated by a carmine-glycerine (1:1) staining procedure and at least 1000 grains for each species were considered. Permanent slides were made using Venetian Turpentine solution as a mounting medium.

Mitotic studies were performed in root tips pretreated with $0.002 \mathrm{M}$ solution of 8-hydroxyquinoline during 4 hat laboratory temperature, fixed in absolute ethanol: glacial acetic acid (3:1) for at least $12 \mathrm{~h}$ at $4{ }^{\circ} \mathrm{C}$ and stained according to the Feulgen's technique (acid hydrolysis in $1 \mathrm{~N} \mathrm{HCl}$ for 10 $\min$ at $60{ }^{\circ} \mathrm{C}$ followed by staining with Schiff's reagent). The meristems were macerated in a drop of $2 \%$ aceto-orcein and then squashed. Permanent slides were made using euparal as a mounting medium.

For karyotype description the chromosomes were arranged in groups according to the position of the centromere (median, m; submedian, sm; subtelocentric, st; telocentric, t) and in order of decreasing size in each class. Chromosome nomenclature followed Levan et al. (1964). At least ten best metaphases were selected for making idiograms.

The lengths of chromosome arms were measured on drawings made with a camera lucida (2600). Karyotype asymmetry was estimated using the Mean Centromeric Asymmetry (MCA) and Coefficien of Variation (CVCL) of Peruzzi \& Eroğlu (2013), as well as the categories of Stebbins (1971).

\section{RESULTS}

All the ten populations analyzed of both Callisia species were diploids. However, whereas $C$. repens showed $2 \mathrm{n}=2 \mathrm{x}=12$ chromosomes in the eight populations analyzed (Fig. 1, Table II), Callisia monandra showed $2 \mathrm{n}=2 \mathrm{x}=14$ chromosomes in the two populations studied (Fig. 2, Table II). The eight populations of $C$. repens showed the karyotype formula $2 \mathrm{~m}+2 \mathrm{sm}+6 \mathrm{st}$ $+2 \mathrm{t}$ (Fig. 5, Table II), whereas the two samples analyzed of C. monandra exhibited a karyotype formula which consisted in six metacentric, four submetacentric, and four telocentric chromosomes $(6 \mathrm{~m}+4 \mathrm{sm}+4 \mathrm{st})$ (Fig. 6, Table II). The total length of the chromosome complement for $C$. repens was 59.76 $\mu \mathrm{m}$ and that for $C$. monandra was $42.27 \mu \mathrm{m}$ (Table II). The average chromosome length was $4.98 \mu \mathrm{m}$ for $C$. repens and 3.02 $\mu \mathrm{m}$ for $C$. monandra (Table II). The range of variation in the average chromosome length was between $6.90 \mu \mathrm{m}$ (metacentric, $\mathrm{m}$ ) and $3.74 \mu \mathrm{m}$ (telocentric, $\mathrm{t}$ ) for $C$. repens, and $3.93 \mu \mathrm{m}$ and $2.22 \mu \mathrm{m}$ (both submetacentric, sm) for C. monandra (Table II). Considering CVCL and $\mathrm{R}$ indexes, $C$. repens showed a bimodal karyotype, whereas $C$. monandra showed a unimodal karyotype, since the values were CVCL: 0.25 and R: 1.84 for C. repens and CVCL: 0.19 and R: 1.77 for C. monandra (Table II). The mean centromeric index for $C$. repens (22.36) fell into the subtelocentric category (Table II), since most of their chromosomes are subtelocentric. For $C$. monandra the mean centromeric index (33.30) fit into the submetacentric group (Table II). The intrachromosomal asymmetry indexes MCA (0.68) and $\mathrm{r}>2(0.66)$ indicate that $C$. repens karyotype is asymmetrical (Table II). The same indexes for $C$. monandra, MCA $(0.45)$ and $r>2(0.57)$ show that this karyotype is asymmetric (Table II). Both Callisia species analyzed belong to the category $3 \mathrm{~A}$ of Stebbins (1971) (Table II). 
Gayana Bot. 72(1), 2015

TABLE I. Chromosome numbers (2n, n), provenance and geographical coordinates of the analyzed samples of Callisia repens and C. monandra. TABla I. Números cromosómicos $(2 \mathrm{n}, \mathrm{n})$, procedencia y coordenadas geográficas de las muestras analizadas de Callisia repens y C. monandra.

\begin{tabular}{|c|c|c|c|c|c|}
\hline SPECIES & $2 \mathrm{n}$ & $\mathrm{n}$ & ORIGIN AND COLLECTION NUMBER & LATITUDE & LONGITUDE \\
\hline \multirow[t]{8}{*}{ Callisia repens } & 12 & 6 & ARGENTINA, Misiones, Dept. Capital, Posadas. MarG-12 (MNES, CTES) & $27^{\circ} 24^{\prime} 20^{\prime \prime} \mathrm{S}$ & $55^{\circ} 53^{\prime} 15^{\prime \prime} \mathrm{O}$ \\
\hline & 12 & 6 & $\begin{array}{l}\text { ARGENTINA, Misiones, Dept. Candelaria, Parque Teyú Cuaré. MarG-19 } \\
\text { (MNES, CTES, SI) }\end{array}$ & $27^{\circ} 16^{\prime} 55^{\prime} \mathrm{S}$ & $55^{\circ} 35^{\prime} 43^{\prime \prime} \mathrm{O}$ \\
\hline & 12 & 6 & $\begin{array}{l}\text { ARGENTINA, Misiones, Dept. Iguazú, Cataratas del Iguazú. MarG- } 21 \\
\text { (MNES) }\end{array}$ & $25^{\circ} 41^{\prime} 43^{\prime \prime} \mathrm{S}$ & $54^{\circ} 27^{\prime} 20^{\prime \prime} \mathrm{O}$ \\
\hline & 12 & 6 & ARGENTINA, Misiones, Dept. Capital, Posadas. MG-12 (MNES) & $27^{\circ} 25^{\prime} 25^{\prime \prime} \mathrm{S}$ & $55^{\circ} 54^{\prime} 24^{\prime \prime} \mathrm{O}$ \\
\hline & 12 & 6 & ARGENTINA, Misiones, Dept. Capital, Posadas. MG-30 (MNES) & $27^{\circ} 23^{\prime} 43^{\prime \prime} \mathrm{S}$ & $55^{\circ} 57^{\prime} 10^{\prime \prime} \mathrm{O}$ \\
\hline & 12 & 6 & ARGENTINA, Misiones, Dept. Candelaria, Parque Teyú Cuaré. MG-39 (MNES) & $27^{\circ} 16^{\prime} 47^{\prime \prime} \mathrm{S}$ & $55^{\circ} 35^{\prime} 37^{\prime \prime} \mathrm{O}$ \\
\hline & 12 & 6 & ARGENTINA, Misiones, Dept. Candelaria, Osununú. MG-40 (MNES) & $27^{\circ} 16^{\prime} 50^{\prime \prime} \mathrm{S}$ & $55^{\circ} 34^{\prime} 58^{\prime \prime} \mathrm{O}$ \\
\hline & 12 & 6 & ARGENTINA, Corrientes, Dept. Ituzaingó, Garapé. MG-66 (MNES) & $27^{\circ} 35^{\prime} 37^{\prime \prime} \mathrm{S}$ & $56^{\circ} 18^{\prime} 25^{\prime \prime} \mathrm{O}$ \\
\hline \multicolumn{6}{|c|}{ Callisia monandra } \\
\hline & 14 & 7 & ARGENTINA, Misiones, Dept. Iguazú, Cataratas del Iguazú. MarG-26 (MNES) & $25^{\circ} 40^{\prime} 46^{\prime \prime} \mathrm{S}$ & $54^{\circ} 27^{\prime} 20^{\prime} \mathrm{O}$ \\
\hline & 14 & 7 & ARGENTINA, Misiones, Dept. Iguazú, Cataratas del Iguazú. MarG-68 (MNES) & $25^{\circ} 42^{\prime} 29^{\prime \prime} \mathrm{S}$ & $54^{\circ} 26^{\prime} 20^{\prime \prime} \mathrm{O}$ \\
\hline
\end{tabular}

MarG $=$ Marina Grabiele, $\mathrm{MG}=$ Mauro Grabiele.

The microsporogenesis of the two diploid Callisia species analyzed was normal and the meiotic behaviour was regular. In Callisia repens the chromosomes were associated forming almost exclusively six bivalents (97.21\%) (Fig. 3, Table III), whereas in C. monandra the chromosomes were associated forming exclusively seven bivalents (100\%) at diakinesis and metaphase I (Fig. 4, Table III), being their gametic chromosome numbers $\mathrm{n}=6$ and $\mathrm{n}=7$, respectively. In both taxa studied the meiotic statistics analysis was slightly similar. These values are presented for the first time for these two Commelinaceae species. The diakinesis and metaphase I pollen mother cells (PMCs) showed that $C$. repens and $C$. monandra had mainly ring bivalents $(84.46 \%$ and $60 \%$, respectively) and similar mean chiasmata frequencies per cell (10.92 and 12.44, respectively) (Table III). The chiasmata were mostly distal and only rarely interstitial, C. repens: $84.34 \%$ and C. monandra: $83.92 \%$ (Table III). The average of chiasmata per bivalent was high (C. repens: 1.85 chiasmata / bivalent and C. monandra: 1.78 chiasmata / bivalent). In all PMCs of $C$. repens where chromosomes associated forming six bivalents, five were always closed with two chiasmata, often distal but also interstitial sometimes, one chiasma in each chromosome arm; whereas the pair consisting of the telocentric bivalent was always open, showing a single chiasma on the long arm. The recombination index (IR) affected by the gametic number ( $\mathrm{n}=$ $6 ; n=7)$ and the average of chiasmata by pollen mother cell (PMC) (C. repens: 10.92 and C. monandra: 12.44) was high for the two species analyzed $(C$. repens: $\mathrm{IR}=6+10.92=16.92$; C. monandra: $\mathrm{RI}=7+12.44=19.44)$. Both Callisia species have high stainability of pollen grains (C. repens: $92.76 \%$ and C. monandra: $84.66 \%$ ) (Table III) and in natural conditions showed high seed production.

\section{DISCUSSION}

In this paper the chromosome numbers, karyotype structure and meiotic behaviour in 10 populations belonging to Callisia repens and Callisia monandra (Commelinaceae) from North-Eastern Argentina were studied. No inter-population variability was detected among the studied species.

Callisia repens is a weed present from Mexico and West Indies to Argentina (Hunt 1986). It is found in forest margins, moist banks, rocks, roadsides and waste grounds (Hunt 1983, 1994). The results presented in this paper showed that $C$. repens is diploid with $2 \mathrm{n}=2 \mathrm{x}=12$ chromosomes constituting these results the first record of chromosome number for all these populations from Argentina. These results are consistent with those cited by Romeu-Pitrez et al. (2001) who found the same chromosome number in North-Eastern Brazilian populations. Jones \& Jopling (1972) also cited C. repens with $2 \mathrm{n}=12$ chromosomes for populations from Mexico and Venezuela. Anderson \& Sax (1936), Sax (1932), Hunt (1994), Guervin \& LeCoq (1966) also cited $2 n=12$ for populations of South America and others undefined localities. According to Tucker (1989) and Owens (1981) a tetraploid cytotype with $2 \mathrm{n}=24$ chromosomes for $C$. repens existed in Mexico populations. Lewis et al. (1967) also reported $2 \mathrm{n}=14$ chromosomes for $C$. repens; however, the results presented here and most of previous papers indicate that $2 n=12$ is the most common cytotype for this species.

Callisia monandra is the species with more southern extension range within the section Leptocallisia, and is distributed from Mexico and The Indies to South America, reaching NorthEastern Argentina. In this work, Callisia monandra showed to be a diploid species with $2 \mathrm{n}=2 \mathrm{x}=14$ chromosomes. These results 

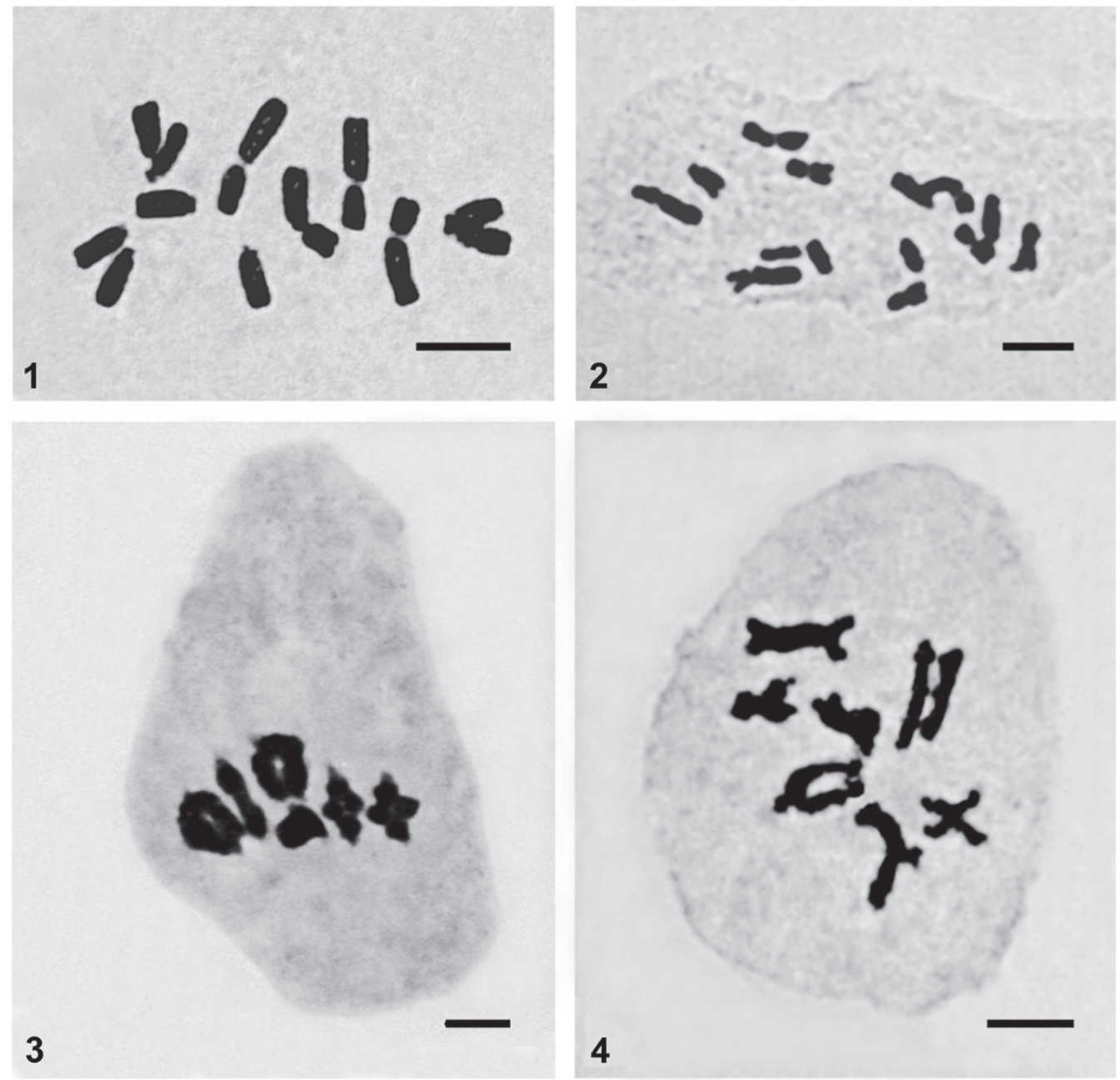

Figuras 1-4. Cromosomas somáticos $(1,2)$ y células madres del polen con cromosomas meióticos $(3,4) .1$, Callisia repens $(2 \mathrm{n}=2 \mathrm{x}=12) .2$, Callisia monandra $(2 \mathrm{n}=2 \mathrm{x}=14) .3$, Callisia repens, metafase I con 6 bivalentes. 4, Callisia monandra, diacinesis con 7 bivalentes. Escala $=5 \mu \mathrm{m}$.

Figures 1-4. Somatic chromosomes $(1,2)$ and pollen mother cells with meiotic chromosomes $(3,4) .1$, Callisia repens $(2 \mathrm{n}=2 \mathrm{x}=12) .2$, Callisia monandra $(2 \mathrm{n}=2 \mathrm{x}=14) .3$, Callisia repens, metaphase I with 6 bivalents. 4, Callisia monandra, diakinesis with 7 bivalents. Scale bars $=5 \mu \mathrm{m}$.

constitute the first record of chromosome number for these southernmost populations from Argentina. The chromosome number $2 \mathrm{n}=14$ exhibited here is consistent with those cited by Jones \& Jopling (1972, as Aploleia monandra (Sw.) H.E.Moore), who counted $2 n=14$ chromosomes in populations from Mexico, while Romeu-Pitrez et al. (2001) obtained the same chromosome number for one Brazilian population.

In Callisia the diploid species are predominant, considering that it was recorded $2 \mathrm{n}=12,14$ and 16 chromosomes in C. fragrans, C. macdougallii Miranda, $C$. elegans Alexander ex H.E.Moore, C. soconuscensis Matuda, C. multiflora (M.Martens \& Galeotti) Standl., C. laui (D.R.Hunt) D.R.Hunt, C. gentlei Matuda, C. warszewicziana (Kunth \& Bouché) D.R.Hunt, C. tehuantepecana Matuda,
C. filiformis M.Martens \& Galeotti) D.R.Hunt, C. graminea (Small) G.C.Tucker, C. rosea (Vent.) D.R.Hunt, C. cordifolia (Sw.) E.S.Anderson \& Woodson, C. monandra and C. repens, and only a few are known to be tetraploid and hexaploid species (Darlington 1929, Anderson \& Sax 1936, Sax 1932, Giles 1942, Guervin \& Lecoq 1965, 1966, Heitz 1968, 1969 , Handlos 1970, Jones \& Jopling 1972, Begum \& Zaman 1980, Alam \& Sharma 1984, Weryszko-Chmielewska 1988, Beltrao \& Guerra 1990, Hunt 1994, Singh 1995). In the present analysis the 10 studied populations of Callisia repens $(2 \mathrm{n}=12)$ and $C$. monandra $(2 \mathrm{n}=14)$ were diploid.

The karyotype formula of Callisia repens consisted in 2 metacentric, 2 submetacentric, 6 subtelocentric and 2 telocentric chromosomes, constituting these results the first 
karyotype description for the species, where morphometric parameters of the karyotype were performed. Anderson \& Sax (1936) mentioned that Callisia repens has six pairs of medium sized chromosomes, of which two of them exhibited submedian constrictions whereas the other four have terminal or subterminal constrictions, however, these authors did not carry out any statistical measurements to arrive at such conclusions. Both samples of Callisia monandra analyzed exhibited a karyotype formula which consisted in six metacentric, four submetacentric, and four telocentric chromosomes. In previous studies in C. monandra, no descriptions of the karyotype were carried out considering the analysis of morphometric parameters. Therefore, the karyotype formula from both Callisia species presented here, are not possible to being compared with other sources. In this sense, all the karyotype features presented in this paper for Callisia repens and $C$. monandra constituted a novelty for the species.

Although the two Callisia species analyzed in the present work are slightly morphologically similar, mainly when young specimens are being compared (Faden 1998), cytologically, Callisia repens and C. monandra, can be distinguished by chromosome numbers and their karyotype formulae.

Centromere positions as well as comparative chromosome size were used as criteria of karyotype symmetry in some plant species, especially in Commelinaceae; and bimodality, a clearcut separation into larger and smaller chromosomes within a complement (Jones \& Jopling 1972), can be seen in only a few genera of this family (Jones \& Jopling 1972, Grabiele et al. 2012). Symmetrical complements are rare in the family and most of the genera have karyotypes which are decidedly asymmetrical, though to varying degrees (Jones \& Jopling

TABLE II. Karyotype parameters in Callisia species. Total chromosome length (TCL); mean chromosome length (c); maximum and minimum chromosome length (c max, c min); mean centromeric index (i); proportion of chromosome pairs with arm ratio $>2$ ( $r>2)$; largest/smallest chromosome ratio (R); ratio of shortest/longest pair (S/L); Mean Centromeric Asymmetry (MCA); Coefficient of Variation (CVCL). Chromosome abbreviations: m, metacentric; sm, submetacentric; st, subtelocentric; t, telocentric.

TABLA II. Parámetros cariotípicos en las especies de Callisia. Longitud total del complemento (LTC); longitud cromosómica media (c); longitud cromosómica máxima y mínima (c max, c min); índice centromérico medio (i); proporción de pares cromosómicos con relación entre brazos $>$ $2(\mathrm{r}>2)$; relación entre la longitud del par mayor y menor del complemento $(\mathrm{R})$; entre la longitud del par más corto y más largo $(\mathrm{S} / \mathrm{L})$; e índice de asimetría centromérica (MCA) y coeficiente de variación (CVCL). Abreviatura de los cromosomas: m, metacéntrico; sm, submetacéntrico; st, subtelocéntrico; t, telocéntrico.

\begin{tabular}{lcc} 
& C. REPENS & C. MONANDRA \\
\hline $2 \mathrm{n}$ & 12 & 14 \\
$\mathrm{x}$ & 6 & 7 \\
Karyotype formula & $2 \mathrm{~m}+2 \mathrm{sm}+6 \mathrm{st}+2 \mathrm{t}$ & $6 \mathrm{~m}+4 \mathrm{sm}+4 \mathrm{st}$ \\
$\mathrm{TCL}$ & $59.76 \mu \mathrm{m}$ & $42.27 \mu \mathrm{m}$ \\
$\mathrm{c}$ & $4.98 \mu \mathrm{m}$ & $3.02 \mu \mathrm{m}$ \\
$\mathrm{c} \max$ & $6.90 \mu \mathrm{m}$ & $3.93 \mu \mathrm{m}$ \\
$\mathrm{c} \min$ & $3.74 \mu \mathrm{m}$ & $2.22 \mu \mathrm{m}$ \\
$\mathrm{i}$ & 22.36 & 33.30 \\
MCA & 0.68 & 0.45 \\
CVCL & 0.25 & 0.19 \\
$\mathrm{R}$ & 1.84 & 1.77 \\
$\mathrm{r}>2$ & 0.66 & 0.57 \\
S/L & 0.54 & 0.61 \\
Stebbin's category & $3 \mathrm{~A}$ & $3 \mathrm{~A}$
\end{tabular}

TABLE III. Meiotic chromosome association at diakinesis and metaphase I of Callisia repens and C. monandra.

TABLA III. Asociación cromosómica meiótica en diacinesis y metafase I de Callisia repens y C. monandra.

\begin{tabular}{lcc} 
& C. REPENS & C. MONANDRA \\
\hline Bivalents per cell $\pm \mathrm{SE}$ & \multicolumn{2}{c}{} \\
Rings & $0.92 \pm 0.06$ & $2.78 \pm 0.14$ \\
Rods & $5.00 \pm 0.00$ & $4.22 \pm 0.14$ \\
Total & 5.92 & 7 \\
Chiasmata per cell $\pm \mathrm{SE}$ & & $2 \pm 0.23$ \\
Interstitials & $1.71 \pm 0.26$ & $10.44 \pm 0.26$ \\
Distals & $9.21 \pm 0.28$ & $12.44 \pm 0.29$ \\
Total & $10.92 \pm 0.06$ & $1.78 \pm 0.04$ \\
Chiasmata per bivalent \pm SE & $1.85 \pm 0.01$ & 84.66 \\
Pollen stainability $(\%)$ & 92.76 &
\end{tabular}



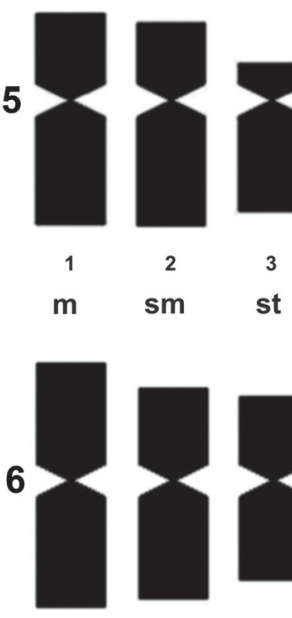

m
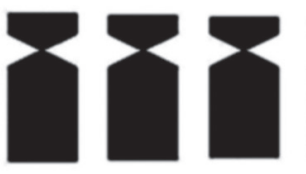

5

6

st
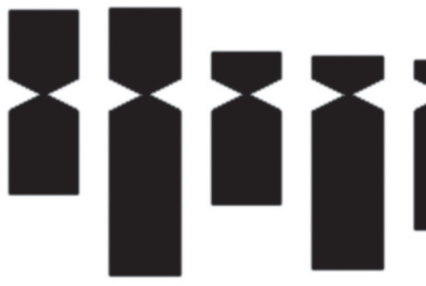

st

Figures 5-6. Idiograms. 5, Callisia repens $(2 \mathrm{n}=2 \mathrm{~m}+2 \mathrm{sm}+6 \mathrm{st}+2 \mathrm{t}) .6$, Callisia monandra $(2 \mathrm{n}=6 \mathrm{~m}+4 \mathrm{sm}+4 \mathrm{st})$. Scale bars $=1 \mu \mathrm{m}$. Figuras 5-6. Idiogramas. 5, Callisia repens $(2 \mathrm{n}=2 \mathrm{~m}+2 \mathrm{sm}+6 \mathrm{st}+2 \mathrm{t}) .6$, Callisia monandra $(2 \mathrm{n}=6 \mathrm{~m}+4 \mathrm{sm}+4 \mathrm{st})$. Escala $=1 \mu \mathrm{m}$.

1972). In this sense, both taxa of the same genus analyzed here showed some differences regarding to this. While $C$. repens showed a bimodal asymmetrical karyotype, the karyotype of C. monandra was shown to be unimodal and asymmetrical. Bimodal karyotypes were demonstrated for Tripogandra species, other member of Commelinaceae familiy (Grabiele et al. 2012). This congruence is not a surprise, because Callisia is included into subtribe Tradescantiinae Rohweder together with Tripogandra and Tradescantia (Rohweder 1956). Mean values obtained for the shortest/longest pair ratio $(\mathrm{S} / \mathrm{L})$ and the Coefficient of Variation (CVCL) indicate that there is little variation in the sizes of the chromosomes in C. monandra, so the greatest variation is that for $C$. repens karyotype.

According to the Mean Centromeric Asymmetry (MCA), Callisia monandra indicated trend of metacentric chromosomes (as shown by the results of karyotype studied), whereas in $C$. repens, the MCA value was higher than in C. monandra, which is according to the highest number of subtelocentric and telocentric chromosomes than to the number of metacentric and submetacentric chromosomes. The karyotype of $C$. repens was the most asymmetrical of the two species analyzed, and exhibited the greatest variation in length among the chromosomes. The differences between the chromosome arms are moderate in C. monandra while in $C$. repens tends to be from moderate to high. Some moderate degrees of karyotype asymmetry and gradual differences in chromosome sizes were also shown in Commelina species, another member of the
Commelinaceae family (Grabiele et al. 2005).

The results obtained from the analysis of the meiotic behaviour are given for the first time for Callisia monandra, whereas the chiasmata frequency and distribution constitute a novelty for $C$. repens and $C$. monandra. The regular behaviour in the PMCs of $C$. repens confirmed that the basic number of the species is $\mathrm{x}=6$ and these data are consistent with those of Jones \& Jopling (1972), who also proposed $x$ $=6$ as the ancestral basic chromosome number for the entire genus Callisia. Handlos (1970) and Anderson \& Sax (1936) also proposed the ancestral basic chromosome number $\mathrm{x}=$ 6 for the genus. However, in Callisia monandra, both the exclusive association of seven bivalents in the PMCs and the regular behaviour, together with previous information (Jones \& Jopling 1972, which mentioned this species under the name Aploleia monandra), confirmed that the basic number of this species is $\mathrm{x}=7$.

Chromosomal characteristics such as size and volume chromosomal and quantity of DNA, allow inferring about the karyotype evolution of Callisia. Guervin et al. (1975) observed a polyploid series with $2 \mathrm{n}=12,24$ and 48 for $C$. repens, $C$. multiflora and $C$. insignis, respectively. The increase in chromosome number corresponded to a reduction in the chromosome size, which was related to a trade-off associated with polyploidy. Bergamo (2003), analyzing Callisia and Tripogandra species suggested an ancestral basic number $\mathrm{x}=$ 8 , currently conserved in C. warszewicziana and Tripogandra. 
The clades of section Callisia $(\mathrm{x}=6)$ and one other that group most species of section Leptocallisia $(\mathrm{x}=7)$ have undergone independent dysploid reductions (Bergamo 2003). Another dysploid reduction would have occurred in C. gracilis $(\mathrm{x}=7)$ of section Leptocallisia, which appears in the clade of Tripogandra demonstrating that the genus is polyphyletic. Thereby, according to Bergamo (2003) in the genus, the chromosomal loss would be more common than chromosomal gain.

The Callisia species studied here are clearly based on $\mathrm{x}=$ $6(C$. repens $)$ and $\mathrm{x}=7$ (C. monandra), the two most common basic chromosome numbers in the genus. Hunt (1986) considering the morphological features and the chromosome numbers divided the species of Callisia into five sections; C. monandra along with 5 other species belongs to section Leptocallisia, which species are characterized by having a basic chromosome number $\mathrm{x}=7$. The remaining sections have a basic number $\mathrm{x}=6$, as section Callisia, which includes Callisia repens; with the exception of sections Brachyphylla $(\mathrm{x}=6,8)$ and Hadrodemas $(\mathrm{x}=8)$. Thereby, the gametic number $\mathrm{n}=7$ confirms the basic number $\mathrm{x}=7$ proposed for C. monandra (Jones \& Jopling 1972, as Aploleia monandra), which is probably derived from $x=6$, since $x=6$ is the most represented basic chromosome number of the genus (Anderson \& Sax 1936, Handlos 1970, Jones \& Jopling 1972). Furthermore, the observation of a regular meiotic chromosomal behaviour and the exclusive association of 7 bivalents in all the PMCs analyzed do not provide conclusive data on the origin of this basic number. Therefore, probably the karyotype of $C$. monandra is derivative with respect to the ancestral karyotype considered for the genus, and the higher occurrence of metacentric chromosomes could be explained by chromosomal fission phenomena followed by translocations, something that was previously proposed for the genus Gibasis, also belonging to Commelinaceae (Kenton 1981). Also, the direction of the dysploidy, can only be explained when these numbers are plotted against a robust phylogenetic tree. However, more detailed analysis of the karyotype through classical and molecular cytogenetics are necessary in $C$. monandra and the closest species with $\mathrm{x}=6,8$ to resolve the origin of $\mathrm{x}=7$.

Callisia repens and Callisia monandra exhibit sympatric distribution and reach the southernmost area of the geographical range of the whole genus. They have been also morphologically confused (Faden 1998). Therefore, the detailed cytogenetic analysis presented here is of great importance for solving taxonomic problems between these two species; and further, in future studies it would be interesting to include karyotype analysis of all species of the genus Callisia. In this sense, the knowledge of apparently simple cytogenetic characteristics of a species, such as chromosome number, basic number, meiotic behaviour of chromosomes, the gametic number and fertility of individuals, can contribute to better understand the complex patterns of morphological variation and to help define taxonomic boundaries between species.

\section{ACKNOWLEDGEMENTS}

During the course of this work Marina Grabiele was a fellow of Comité Ejecutivo de Desarrollo e Innovación Tecnológica (CEDIT, Gobierno Provincia de Misiones, Argentina). The authors are grateful to Ms. Irma Stella Insaurralde de Lirussi for her taxonomic assistance and Dr. Mauro Grabiele for providing some plant materials as well as for helpful comments. This work was partially supported by PICT-O 36907 (ANPCyT - SECyT, Argentina) and a doctoral fellowship of CONICET (Argentina) awarded to Marina Grabiele.

\section{REFERENCES}

Alam, N. \& A.K. Sharma. 1984. Trends of Chromosome evolution in family Commelinaceae. Nucleus 27: 231-241.

Anderson, E. \& K. SAX. 1936. A cytological monograph of the American species of Tradescantia. Botanical Gazette (Crawfordsville) 97: 433-476.

Bacigalupo, N.M. 1964. Estudio sobre las Commelinaceaes Argentinas I. Darwiniana 13: 87-103.

BaCigalupo, N.M. 1996. Commelinaceae. En: F.O. Zuloaga \& O. Morrone (eds.), Catálogo de las plantas vasculares de la República Argentina I. Pteridophyta, Gymnospermae y Angiospermae Monocotyledoneae. Monographs of the Missouri Botanical Garden 60: 123-128.

Begum, R. \& M.A.ZAman. 1980. Cytogenetics of the Commelinaceae. $\mathrm{X}$. Karyomorphology and meiotic behaviour of Callisia elegans Alexander. Bangladesh Journal of Botany 9: 92-96.

Beltrao, R.C. \& M. Guerra. 1990. Citogenética de angiospermas colectadas en Pernambuco - III. Ciência e Cultura 42: 839-845.

Bergamo, S. 2003. A phylogenetic evaluation of Callisia Loefl. (Commelinaceae) based on molecular data. PhD Thesis, University of Georgia, USA. 160 pp.

Darlington, C.D. 1929. Chromosome behaviour and structural hibridity in the Tradescantieae. Journal of Genetics 21: 207-86.

FADEN, R.B. 1998. Commelinaceae. In: K. Kubitzki (ed.), The families and genera of vascular plants. Vol. 4. Flowering plants, monocotyledons, Alismatanae and Commelinanae (except Gramineae). Berlin and Heidelberg: Springer 109-128.

Giles, N.H. 1942. Autopolyploidy and geographical distribution in Cuthbertia graminea Small. American Journal of Botany 29: 637-645.

GolczyK, H., R. HasteroK \& A.J. JoAchimiak. 2005. FISH-aimed karyotyping and characterization of Renner complexes in permanent heterozygote Rhoeo spathacea. Genome 48: 145-153.

Grabiele, M., J.R. Daviña \& A.I. Honfi. 2005. Chromosomes of four species of Commelina (Commelinaceae). Botanical Journal of Linnaean Society 148: 207-218.

Grabiele, M., A.I. Honfi \& J.R. Daviña. 2012. Cytotaxonomy of Tripogandra diuretica and Tripogandra glandulosa (Commelinaceae) from NE Argentina. Plant Biosystems 146: 309-316.

Guervin, C. \& C. LeCoq. 1965. Caryologie du Callisia elegans Alexander. Bulletin de la Société Botanique de France 112: 225-233.

Guervin C. \& C. Lecoq. 1966. Caryologie des Commelinaceés. II. Les Callisia repens L. et $C$. insignis C. B. Clarke. Bulletin 
du Muséum National d'histoire Naturelle (Paris) 38: 497-506.

Guervin, C., C. LecoQ \& J. Laroche. 1975. Utilisation des quantités totales et des densités d'ADN nucléaire pour retracer la phylogenèse chez le genre Callisia (Commélinacées). Comptes Rendus de L'Académie des Sciences Paris 227: 1005-1007.

Handlos, W.L. 1970. Cytological Investigations of Commelinaceae from Mexico. Baileya 17: 6-33.

Heitz, B. 1968. Commélinaceés. II. Informations Annuelles de Caryosystematiques et Cytogénetiques 2: 26-32.

Heitz, B. 1969. Commélinaceés. Informations Annuelles de Caryosystematiques et Cytogénetiques 3: 9-12.

Hunt, D.R. 1983. Commelinaceae. In: R. McVaugh (ed.), Flora Novo Galiciana, Vol 15. Bromeliaceae to Dioscoreaceae. Michigan, USA: Michigan Herbarium 130-201.

Hunt, D.R. 1986. A revision of Gibasis Rafin. American Commelinaceae XII. Kew Bulletin 41: 107-129.

Hunt, D.R. 1994. Commelinaceae. In: G. Davidse, M. Sousas \& A.O. Chater (eds.), Flora Mesoamericana, Alismataceae a Cyperaceae, Vol 6. Mexico DF: Universidad Nacional Autonoma de Mexico; St Louis: Missouri Botanical Garden; London: The Natural History Museum 157-173.

Jones, K. 1974. Chromosome evolution by Robertsonian translocation in Gibasis (Commelinaceae). Chromosoma (Berl.) 45: 353-368.

JoNES, K. 1990. Robertsonian change in allies of Zebrina (Commelinaceae). Plant Systematic and Evolution 172: 263-271.

JoNES, K. \& C. JopLING. 1972. Chromosomes and the classification of the Commelinaceae. Botanical Journal of Linnaean Society 65: $129-162$.

Jones, K. \& A. Kenton. 1984. Mechanisms of chromosome change in the evolution of the tribe Tradescantieae (Commelinaceae). In: A.K. Sharma \& A. Sharma (eds.), Chromosomes in Evolution of Eukaryotic Groups Vol II, C.R.C. Press, Florida 143-168.
Kenton, A. 1981. Chromosome evolution in the Gibasis linearis alliance (Commelinaceae). I. The Robertsonian differentiation of G. venustula and G. speciosa. Chromosoma 84: 291-304.

Kenton, A., A. Davies \& K. Jones. 1987. Identification of Renner complexes and duplications in permanent hybrids of Gibasis pulchella (Commelinaceae). Chromosoma 95: 424-434.

Levan, A., K.L. Fredga \& A.A. Sandberg. 1964. Nomenclature for centromeric position on chromosomes. Hereditas 52: 201-220.

LEWIS, W.H., Y. SudA \& R.L. Oliver. 1967. In Chromosome numbers of phanerogams. 2. Annals of the Missouri Botanical Garden 54: $178-181$.

Owens, S.J. 1981. Self-incompatibility in the Commelinaceae. Annals of Botany 47: 567-581.

PeruZZI, L. \& H. ERoĞLu. 2013. Karyotype asymmetry: again, how to measure and what to measure? Comparative Cytogenetics 7: 1-9.

RoHweder, O. 1956. Die Farinosae in der Vegetation von El Salvador. Abhandlungen aus dem Gebiet der Auslandskunde 61: 98-178.

Romeu-Pitrez, S., F.L. Pessoa, R. Barreto \& M. Guerra. 2001. Números cromossomicos de especies de Commelinaceae R. Br. ocorrentes no nordeste do Brasil. Boletin Botanico da Universidade do Sao Paulo 19: 7-14.

SAX, K. 1932. The cytological mechanism of crossing over. Journal of the Arnold Arboretum 13: 180-367.

SiNGH, R.N. 1995. New chromosome count of dodecaploidy in Spironema fragrans Lindle. CIS Chromosome Information Service 58: 28-29.

StebBins, G.L. 1971. Chromosomal evolution in higher plants. Reading: Addison-Wesley, New York. 216 pp.

TuCKER, G.C. 1989. The genera of Commelinaceae in the Southeastern United States. Journal of the Arnold Arboretum 70: 97-130.

Weryszko-Chmielewska, E. 1988. Analysis of the karyotype of Callisia elegans Alexand. (Commelinaceae) including differential staining of chromosomes. Acta Societatis Botanicorum Poloniae 57: 317-327.

APPENDIX: Quantitative parameters of chromosomes. s: mean short arm length, 1: mean long arm length, c: mean chromosome length, i: mean centromeric index, SE: standard error.

ApÉNDICE: Parámetros cuantitativos de los cromosomas: s: longitud promedio del brazo corto, 1: longitud promedio del brazo largo, c: longitud promedio cromosómica, i: índice centromérico, SE: error estándar.

\begin{tabular}{|c|c|c|c|c|c|}
\hline PAIR & $\mathrm{s}(\mu \mathrm{m}) \pm \mathrm{SE}$ & $1(\mu \mathrm{m}) \pm \mathrm{SE}$ & $\mathrm{c}(\mu \mathrm{m}) \pm \mathrm{SE}$ & $\mathrm{i}$ & TYPE \\
\hline \multicolumn{6}{|c|}{ Callisia repens } \\
\hline 1 & $2.75 \pm 0.03$ & $4.15 \pm 0.07$ & $6.90 \pm 0.08$ & 39.85 & $\mathrm{~m}$ \\
\hline 2 & $2.33 \pm 0.02$ & $4.21 \pm 0.08$ & $6.54 \pm 0.09$ & 35.62 & $\mathrm{sm}$ \\
\hline 3 & $0.86 \pm 0.05$ & $3.48 \pm 0.03$ & $4.34 \pm 0.07$ & 19.81 & st \\
\hline 4 & $0.58 \pm 0.00$ & $3.61 \pm 0.05$ & $4.19 \pm 0.05$ & 13.84 & st \\
\hline 5 & $0.62 \pm 0.02$ & $3.54 \pm 0.07$ & $4.16 \pm 0.09$ & 14.90 & st \\
\hline 6 & $0.38 \pm 0.00$ & $3.36 \pm 0.05$ & $3.74 \pm 0.06$ & 10.16 & $\mathrm{t}$ \\
\hline \multicolumn{6}{|c|}{ Callisia monandra } \\
\hline 1 & $1.73 \pm 0.06$ & $1.86 \pm 0.10$ & $3.59 \pm 0.15$ & 48.26 & $\mathrm{~m}$ \\
\hline 2 & $1.36 \pm 0.10$ & $1.76 \pm 0.03$ & $3.12 \pm 0.10$ & 43.52 & $\mathrm{~m}$ \\
\hline 3 & $1.21 \pm 0.07$ & $1.46 \pm 0.10$ & $2.67 \pm 0.16$ & 45.32 & $\mathrm{~m}$ \\
\hline 4 & $1.25 \pm 0.07$ & $2.68 \pm 0.15$ & $3.93 \pm 0.16$ & 31.78 & $\mathrm{sm}$ \\
\hline 5 & $0.61 \pm 0.04$ & $1.62 \pm 0.08$ & $2.22 \pm 0.12$ & 27.27 & $\mathrm{sm}$ \\
\hline 6 & $0.54 \pm 0.04$ & $2.58 \pm 0.15$ & $3.12 \pm 0.14$ & 17.28 & st \\
\hline 7 & $0.49 \pm 0.01$ & $2.00 \pm 0.13$ & $2.49 \pm 0.12$ & 19.69 & st \\
\hline
\end{tabular}

Recibido: 11.02 .14

Aceptado: 11.08.14 